\title{
Tissue Distribution and Biomagnification of Polybrominated Diphenyl Ethers in Snakes From Paddy Fields in the Yangtze River Delta, Southeastern China
}

\section{Xiuming Jing}

Chinese Academy of Geological Sciences Institute of Geophysical and Geochemical Exploration

Xueqiu Wang ( $\square$ geo-chemistry@hotmail.com )

Chinese Academy of Geological Sciences Institute of Geophysical and Geochemical Exploration Hongjuan Lv

Chinese Academy of Geological Sciences Institute of Geophysical and Geochemical Exploration Futian Liu

Chinese Academy of Geological Sciences Institute of Geophysical and Geochemical Exploration

\section{Research Article}

Keywords: PBDE, snake, tissue burden, biomagnification, Yangtze River Delta

Posted Date: January 18th, 2022

DOI: https://doi.org/10.21203/rs.3.rs-1191979/v1

License: (1) (1) This work is licensed under a Creative Commons Attribution 4.0 International License.

Read Full License 


\section{Abstract}

In many developing regions, the rapid development in industrialization and urbanization has caused adverse impact on the aqueous ecology and environment. However, there is limited information available on the tissue-specific burden and biomagnification of polybrominated diphenyl ethers (PBDEs) in biota. In the present study, the tissue concentration and distribution of tri- to deca-BDEs were analyzed in terrestrial short-tailed mamushi (Gloydius Brevicaudus) and semi-aquatic red-backed rat snake (Elaphe Rufodorsata) from the Yangtze River (ChangJiang) Delta, Southeastern China. The total PBDE concentrations of liver, muscle and adipose tissues in two snakes ranged from 29.1-252.2, 10.5-48.9 and 4.36-106.4 ng/g Iw, respectively. The congener patterns of PBDEs exhibited the significant difference between two snakes, which may be attributed to different feeding habits and dermal exposure. Tissuespecific burdens in snakes suggested that adipose tissue served as a dominant storage and sink for PBDEs ( $85.1 \%$ for red-backed rat snake and $80.0 \%$ for short-tailed mamushi, respectively) compared to liver ( $8.1 \%$ and $12.5 \%$, respectively) and muscle (6.9\% and $7.5 \%$, respectively) tissues. Biomagnification potential of PBDEs was investigated via black spotted frogs-red-backed rat snake food chain. The biomagnification factors (BMFs) of tri- to deca-BDEs were in a range of 0.74 to 4.30 . Tetra- to octa-BDEs generally exhibited biomagnification potentials through the frog-snake food chain. Moreover, parabolic relationship was observed between BMFs and log Kow of PBDE congeners, and it may be resulted from the combined effects of chemical's hydrophobicity and molecular size. This research, thereby provides data support for biological monitoring being concerned about liver, muscle and adipose tissues of animals.

\section{Introduction}

Polybrominated diphenyl ethers (PBDEs), are a group of additive flame retardants that have been extensively utilized in many types of electronic products and furniture.(Besis and Samara, 2012) After a rapid increase in use over three decades, the global production of PBDEs reached approximately 310000 tons in 2000 (Stapleton et al., 2011). Because PBDE congeners can easily escape from their host materials into the environment during production, use, and especially from disposal,(Sjodin et al., 2003) they have been routinely detected in a variety of environment matrices (Hites, 2004), food (Domingo, 2012; Schecter et al., 2004) and wildlife (Currier et al., 2020; Wu et al., 2020). However, PBDEs were, unexpectedly, found to be environmentally persistent due to the resistance to various degradation (Besis and Samara, 2012), and their high lipophilicity resulted in a strong bioaccumulation potential (Weijs et al., 2009). Together with their toxic effects, commercial penta- and octa-BDE mixtures have been banned globally under the Stockholm Convention in 2006, and deca-BDE mixtures in 2017 (Sharkey et al., 2020). Despite the strict restrictions on these chemicals, PBDEs are ubiquitously presented in the environment and their residues can transfer and become incorporated into body tissue of living creatures (Zhou et al., 2016b). To data, basic information on these contaminant burdens in biota are relative limited, significantly restricting human and environmental health evaluations 
Reptiles are a major group of vertebrate animals that occupies relatively high trophic positions in aquaticterrestrial ecosystems (Du et al., 2020). Since many reptiles are long-lived species with poor long-distance dispersal abilities, they are accessible to long-term exposure of organic pollutants and subsequent bioaccumulation (Hopkins, 2000). Nevertheless, reptiles were currently one of the least studied vertebrate group in ecotoxicology (Sparling et al., 2010). The existing researches on reptiles primarily concentrated on turtles and/or crocodilians, while those on squamates were still rare (Wu et al., 2020).

Moreover, although there is growing concern on the bioaccumulation and biomagnification potential of PBDEs, most related studies were conducted based on the whole body concentrations, which increased the uncertainties in the estimates of biomagnification potential.(Conder et al., 2008) For example, previous field observations found that PBDEs were generally biomagnified in the North Sea (Weijs et al., 2009), the Atlantic coast (Shaw et al., 2012), and Coastal Florida (Johnson-Restrepo et al., 2005), while the rapid rates of depuration though biotransformation in the Canadian Arctic was simultaneously suggested (Kelly et al., 2008). The inconsistent and widely varying results indicate that further research is urgently needed to investigate the tissue distribution of PBDEs and their biomagnification potential based on tissue-specific in food web.

In the present study, two snake species were collected from paddy fields in the Yangtze River (ChangJiang) Delta (YRD), China. Tri- to deca-BDE congeners were determined in different tissues (including liver, muscle, and adipose) of short-tailed mamushi (Gloydius brevicaudus) and red-backed rat snake (Elaphe rufodorsata). Our objectives were to (a) investigate the occurrence and congener patterns of PBDEs in snakes; (b) determine the tissue distribution and mass burden of PBDEs in two snake species; and (c) compare the different biomagnification potential of PBDE congeners based on concentrations of frog and snake muscle.

\section{Materials And Methods 2.1 Sampling}

In October 2011, 7 short-tailed mamushi (Gloydius brevicaudus) samples, 9 red-backed rat snake (Elaphe rufodorsata) samples, and 45 frog samples (black-spotted frog, Pelophylax nigromaculatus) were collected from paddy fields in YRD, China. The sampling sites were located between Shanghai and Jiaxing City. Muscle, liver, and adipose (abdominal fat) samples were scrupulously dissected from 16 snake individuals, and these samples were weighted before treatment. After freeze-dried, the muscle tissues were homogenized in a powder under liquid nitrogen. The muscle mixtures, the fresh liver and adipose of snakes were then stored at $-20^{\circ} \mathrm{C}$ until analysis. The frogs were dissected (for muscle), freezedried and stored using same procedure of snakes.

\subsection{Chemicals, extraction and analysis}

All PBDE congeners (BDE-28, -47, -66, -85, -99, -100, -153, -154, -183, -194, -195, -196, -197, -199, -201, -202, $-204,-205,-206,-207,-208$ and -209$)$, and internal standard ( ${ }^{13}$ C-labeled BDE-77) were gained from 
AccuStandard (New Haven, CT). The surrogate standards $\left({ }^{13} \mathrm{C}\right.$-labeled BDE-209 and 2,4,5,6-tetrachloromxylene (TCMX)) from Sigma-Aldrich (Bellefonte, PA, USA) were used to monitor chemical's losses in treatment process. Chemical solutions, like hexane, dichloromethane (DCM) and acetone of analytical grade, were purchased from Beijing Chemical Factory (Beijing, China). Prior to use, anhydrous sodium sulfate (Beijing Chemical Factory, Beijing, China) were activated at $350{ }^{\circ} \mathrm{C}$ for $4 \mathrm{~h}$.

The extraction and clean-up procedures mainly followed the previously reported method with some modifications (Zhou et al., 2016a). In brief, approximately $2 \mathrm{~g}$ (dry weight) muscle sample and $2 \mathrm{~g}$ (fresh weight) of liver and adipose samples mixed with $5 \mathrm{~g}$ anhydrous sodium sulfate was spiked with surrogate standards $\left({ }^{13} \mathrm{C}\right.$-labeled BDE-209 and TCMX). Each sample was Soxhlet extracted with $200 \mathrm{ml}$ of hexane/DCM/acetone (1:1:1 v/v) for $24 \mathrm{~h}$. Lipid contents were determined gravimetrically and removed afterwards by treatment with concentrated sulfuric acid. A Pasteur pipette, filled with $0.2 \mathrm{~g}$ activated silica gel and $1.0 \mathrm{~g}$ acidified silica gel (activated silica/concentrated sulfuric acid, 2:1 w/w) on top was used for further clean-up. After clean-up, each column was conditioned with $7 \mathrm{ml}$ hexane, the extract was added and the analytes eluted with hexane/DCM $(10 \mathrm{~mL}, 1: 1, \mathrm{v} / \mathrm{v})$. The extract volume was reduced to near dryness by a gentle stream of nitrogen gas, and then the residue was dissolved to $0.2 \mathrm{~mL}$ hexane. Internal standard $\left({ }^{13} \mathrm{C}\right.$-labeled BDE-77) was added into the samples before instrumental analysis.

Analysis of PBDEs was performed by gas chromatography (Agilent 7890A) coupled to a mass spectrometry (5975C) using chemical ionization ion source and selective ion monitoring mode (scanning bromine ions $\mathrm{m} / \mathrm{z} 79$ and 81). A DB-5MS column ( $15 \mathrm{~m} \times 0.25 \mathrm{~mm}$ i.d. $\times 0.10 \mathrm{~mm}$ film thickness; Agilent $\mathrm{J} \& \mathrm{~W}$ ) was applied with helium and methane as carrier and reagent gas, respectively. The oven program was $80^{\circ} \mathrm{C}$ for $2 \mathrm{~min}, 15^{\circ} \mathrm{C} / \mathrm{min}$ to $300^{\circ} \mathrm{C}, 2^{\circ} \mathrm{C} / \mathrm{min}$ to $310^{\circ} \mathrm{C}$ and hold for $5 \mathrm{~min}$. The temperature of injector, ion source and transfer line were set at $280^{\circ} \mathrm{C}, 200^{\circ} \mathrm{C}$ and $290^{\circ} \mathrm{C}$, respectively.

\subsection{Stable isotope analysis}

Stable isotope analysis was applied in this study to investigate the diet preferences of snakes and confirmed whether the black-spotted frog observed in the surrounding was their potential prey specie. Detailedly, a Flash HT element analyzer interfaced coupled with a Thermo Scientific MAT 253 isotope ratio mass spectrometer was performed to analyze the carbon isotope $\left(\delta^{13} \mathrm{C}\right)$ and nitrogen isotope $\left(\delta^{15} \mathrm{~N}\right)$. The data set on the stable isotope analysis can be found elsewhere, in which the analysis result was stated and detailed out (Zhou et al., 2016a).

\subsection{Quality assurance/quality control}

Procedural blanks were included in every five samples to test background level. Isotopically-labeled surrogate standard was spiked in every sample accounting for processing losses and matrix effects. Limits of quantification for PBDEs (LOQs) were calculated as average blank level $(n=10)$ plus ten times the standard deviation of the blank (SD), ranging from 0.04 to $0.82 \mathrm{ng} / \mathrm{g}$. The recoveries of surrogate standards were $82 \pm 15 \%$ for ${ }^{13} \mathrm{C}$-labeled BDE-209 and $94 \pm 8 \%$ for TCMX.

\subsection{Statistical analysis}


For the statistical analysis of PBDE congeners in this study, data detected below LOQ were substituted with the value $\mathrm{LOQ} / \sqrt{ } 2$. Descriptive statistics, Student's t-test and Spearman rank correlation were performed using SPSS Statistics Version 23 (IBM Corp.). The significance level was set at $1 \%$. The independent samples $t$ test was used to assess the significant difference between two groups of data. The $\log K_{\mathrm{ow}}$ values of PBDE congeners were gained from previous studies (Tittlemier et al., 2002; Yue and $\mathrm{Li}, 2013)$.

\section{Results And Discussion}

\subsection{Occurrence and Congener Group Patterns}

Once ingested from diet, hydrophobic organic contaminants (HOCs) were taken up in the gastrointestinal tract, firstly passed through the liver and then redistributed to other organs such as muscle before being finally stored in adipose tissue (Du et al., 2020). The concentrations of PBDE congener groups in liver, muscle, and adipose tissues of two snake species are summarized in Table 1. Hexa-, octa- and nonaBDEs were detected in all tissue samples of two snakes. The total PBDE concentrations of liver, muscle, and adipose tissues ranged from 29.1-252.2, 10.5-48.9 and 4.36-106.4 ng/g lw, respectively. The average $\Sigma$ PBDEs concentration in muscle samples of short-tailed mamushi $(23.1 \mathrm{ng} / \mathrm{g} \mathrm{lw})$ was close to those of red-backed rat snake analyzed in the present study $(33.2 \mathrm{ng} / \mathrm{g} \mathrm{Iw})$ and our previous report $(28.3 \mathrm{ng} / \mathrm{g} \mathrm{lw})$ (Zhou et al., 2016b), but was 1-2 orders of magnitude lower than of water snakes sampled from e-waste sites (Liu et al., 2018; Wu et al., 2013; Wu et al., 2020). Additionally, a significant positive correlation was observed between body weight of snakes and muscle concentrations of PBDEs in all samples $\left(r^{2}=0.56\right.$, $p<0.01$; data not shown). This result suggested that the PBDE exposure of snakes might increase with their growth stages. The research focusing on PBDE levels in other tissue of reptiles was relatively limited. Wu et al. (2014) reported that the PBDE exposure of liver sample of Chinese alligators was 920 $\mathrm{ng} / \mathrm{g}$ Iw, significantly higher than the snakes observed in the present study. 
Table 1

Tissue concentrations ( $\mathrm{ng} / \mathrm{g} / \mathrm{w}$ ) of tri- to deca-BDEs of two snake species.

\begin{tabular}{|c|c|c|c|c|c|c|}
\hline \multirow{2}{*}{$\begin{array}{l}\text { species } \\
\text { tissue }\end{array}$} & \multicolumn{3}{|c|}{ red-backed rat snake } & \multicolumn{3}{|c|}{ short-tailed mamushi } \\
\hline & liver & muscle & adipose & liver & muscle & adipose \\
\hline \multirow[t]{2}{*}{ tri-BDE } & $0.09 \pm 0.28$ & $0.39 \pm 0.8$ & $\begin{array}{l}0.002 \pm \\
0.005\end{array}$ & $0.56 \pm 0.77$ & $\begin{array}{l}0.43 \pm \\
0.43\end{array}$ & $\begin{array}{l}0.001 \pm \\
0.003\end{array}$ \\
\hline & (nd-0.83) & (nd-2.2) & (nd-0.01) & (nd-2.22) & (nd-1.13) & (nd-0.01) \\
\hline \multirow[t]{2}{*}{$\begin{array}{l}\text { tetra- } \\
\text { BDE }\end{array}$} & $0.95 \pm 2.76$ & $\begin{array}{l}0.35 \pm \\
0.62\end{array}$ & $\begin{array}{l}0.660 \pm \\
1.78\end{array}$ & $0.86 \pm 0.7$ & $0.11 \pm 0.1$ & $0.100 \pm 0.1$ \\
\hline & (nd-8.32) & $\begin{array}{l}(0.02- \\
1.97)\end{array}$ & $(0.01-5.41)$ & (nd-1.97) & $\begin{array}{l}(0.01- \\
0.22)\end{array}$ & (nd-0.26) \\
\hline \multirow[t]{2}{*}{$\begin{array}{l}\text { penta- } \\
\text { BDE }\end{array}$} & $5.43 \pm 5.92$ & $\begin{array}{l}0.40 \pm \\
0.41\end{array}$ & $\begin{array}{l}1.310 \pm \\
1.89\end{array}$ & $5.90 \pm 9.2$ & $\begin{array}{l}0.25 \pm \\
0.26\end{array}$ & $\begin{array}{l}0.910 \pm \\
0.52\end{array}$ \\
\hline & (nd-15.35) & $(0.02-1.2)$ & $(0.23-6.24)$ & (nd-23.22) & $\begin{array}{l}(0.01- \\
0.72)\end{array}$ & $(0.35-1.78)$ \\
\hline \multirow[t]{2}{*}{$\begin{array}{l}\text { hexa- } \\
\text { BDE }\end{array}$} & $\begin{array}{l}33.70 \pm \\
31.7\end{array}$ & $\begin{array}{l}1.12 \pm \\
0.63\end{array}$ & $\begin{array}{l}7.980 \pm \\
12.8\end{array}$ & $\begin{array}{l}35.60 \pm \\
22.1\end{array}$ & $\begin{array}{l}3.42 \pm \\
1.50\end{array}$ & $\begin{array}{l}5.250 \pm \\
3.82\end{array}$ \\
\hline & $(3.1-89.6)$ & $\begin{array}{l}(0.29- \\
2.42)\end{array}$ & $(1.38-41.4)$ & $(5.91-63.4)$ & $\begin{array}{l}(1.63- \\
6.50)\end{array}$ & $(1.91-23.2)$ \\
\hline \multirow[t]{2}{*}{$\begin{array}{l}\text { hepta- } \\
\text { BDE }\end{array}$} & $8.05 \pm 7.36$ & $\begin{array}{l}0.89 \pm \\
0.61\end{array}$ & $\begin{array}{l}2.360 \pm \\
2.87\end{array}$ & $\begin{array}{l}12.01 \pm \\
7.67\end{array}$ & $\begin{array}{l}2.19 \pm \\
1.72\end{array}$ & $\begin{array}{l}5.300 \pm \\
8.97\end{array}$ \\
\hline & (nd-24.8) & (nd-2.31) & $(0.71-9.03)$ & $(2.75-24.9)$ & (nd-5.53) & $(1.20-35.6)$ \\
\hline \multirow[t]{2}{*}{$\begin{array}{l}\text { octa- } \\
\text { BDE }\end{array}$} & $\begin{array}{l}24.80 \pm \\
26.7\end{array}$ & $\begin{array}{l}1.98 \pm \\
2.42\end{array}$ & $\begin{array}{l}3.180 \pm \\
5.12\end{array}$ & $\begin{array}{l}18.10 \pm \\
16.1\end{array}$ & $\begin{array}{l}2.89 \pm \\
2.00\end{array}$ & $\begin{array}{l}4.320 \pm \\
6.47\end{array}$ \\
\hline & $(3.49-88.7)$ & $\begin{array}{l}(0.39- \\
7.15)\end{array}$ & $(0.57-16.5)$ & $(2.37-51.6)$ & $\begin{array}{l}(1.15- \\
6.55)\end{array}$ & $(1.1-28.9)$ \\
\hline \multirow[t]{2}{*}{$\begin{array}{l}\text { nona- } \\
\text { BDE }\end{array}$} & $\begin{array}{l}28.60 \pm \\
15.3\end{array}$ & $\begin{array}{l}8.68 \pm \\
7.45\end{array}$ & $\begin{array}{l}7.770 \pm \\
8.61\end{array}$ & $\begin{array}{l}40.50 \pm \\
25.8\end{array}$ & $\begin{array}{l}4.62 \pm \\
4.17\end{array}$ & $\begin{array}{l}6.480 \pm \\
3.47\end{array}$ \\
\hline & $(12.3-58.3)$ & $\begin{array}{l}(1.62- \\
19.6)\end{array}$ & $(1.29-26.6)$ & $(7.20-71.6)$ & $\begin{array}{l}(1.26- \\
10.7)\end{array}$ & $(3.31-12.9)$ \\
\hline \multirow[t]{2}{*}{$\begin{array}{l}\text { deca- } \\
\text { BDE }\end{array}$} & $\begin{array}{l}31.00 \pm \\
26.1\end{array}$ & $9.34 \pm 5.4$ & $\begin{array}{l}0.350 \pm \\
0.41\end{array}$ & $\begin{array}{l}46.09 \pm \\
28.9\end{array}$ & $\begin{array}{l}6.25 \pm \\
2.14\end{array}$ & $\begin{array}{l}0.310 \pm \\
0.22\end{array}$ \\
\hline & $(7.95-92.2)$ & $\begin{array}{l}(4.67- \\
19.3)\end{array}$ & (nd-1.29) & $\begin{array}{l}(7.62- \\
76.75)\end{array}$ & $\begin{array}{l}(3.91- \\
10.17)\end{array}$ & $(0.14-0.79)$ \\
\hline \multirow[t]{2}{*}{ ¿PBDEs } & $\begin{array}{l}172.60 \pm \\
58.1\end{array}$ & $\begin{array}{l}33.20 \pm \\
10.4\end{array}$ & $\begin{array}{l}28.600 \pm \\
32.7\end{array}$ & $\begin{array}{l}159.60 \pm \\
84.1\end{array}$ & $\begin{array}{l}23.10 \pm \\
6.75\end{array}$ & $\begin{array}{l}19.200 \pm \\
15.8\end{array}$ \\
\hline & $\begin{array}{l}(69.7- \\
230.7)\end{array}$ & $\begin{array}{l}(10.5- \\
48.9)\end{array}$ & $\begin{array}{l}(4.36- \\
106.4)\end{array}$ & $\begin{array}{l}(29.1- \\
252.2)\end{array}$ & $\begin{array}{l}(11.2- \\
40.2)\end{array}$ & $(9.83-68.0)$ \\
\hline
\end{tabular}


The variations of PBDE congener group patterns in different tissues of two snake species, are presented in Figure 1. In liver samples of two snake species, the levels decreased in the order deca-BDE $>$ hexa-BDE $>$ nona-BDE > octa-BDE > hepta-BDE > penta-BDE > tetra-BDE > tri-BDE, contributing to $26.0 \%, 23.9 \%$, $23.4 \%, 15.1 \%, 6.8 \%, 3.9 \%, 0.6 \%$ and $0.2 \%$ of the total PBDE levels, respectively. Deca-BDEs $(36.6 \%)$ were dominant in snake muscle samples followed by nona-BDEs (31.6\%). For adipose samples, nona- and hexa-BDEs were the two most abundant congener groups collectively contributing to $60.3 \%$ of total PBDEs. PBDE patterns predominated by deca-BDEs have been observed in various biotic and abiotic matrices (Li et al., 2018; Li et al., 2019; Wu et al., 2020), which may be due to the fact that deca-BDE was the major congener in in-use PBDE commercial products (Abbasi et al., 2015). Furthermore, deca-BDE would be debrominated down to penta- and octa-BDE congeners in vitro (Chabot-Giguere et al., 2013). Therefore, the higher concentrations of deca-BDE in liver and muscle compared to those in adipose tissue may be indicative of the metabolic fate of deca-BDE in snakes. The congener group patters of PBDEs showed the significant difference $(p<0.01)$ between the two snake species (Figure 1). The most fluctuating congeners were octa-BDE, nona-BDE and hepta-BDE for liver, muscle, and in adipose tissues. The interspecies difference for PBDE exposure may be attributed to different feeding habits and dermal exposure (Du et al., 2018), since the short-tailed mamushi generally lives in the terrestrial environment while the red-backed rat snake prefers the semi-aquatic condition (Du et al., 2020).

\subsection{Tissue Distribution and Tissue-Specific Burden}

Similar tissue distributions of total PBDE levels were observed in two snakes (Figure 1). In most snake samples, the tissue levels followed the order liver $>$ muscle $>$ lipid. This differed from the body distribution of chlorinated paraffins (CPs) in snakes,(Du et al., 2020) which coincided with the lipid contents in different tissues (Table 1). Result from the present study suggested that other factors (e.g. bioaccumulation pathway and metabolism) besides the lipid content might influence the tissue-specific accumulation of PBDEs in both red-backed rat snake and short-tailed mamushi. Sun et al. (2017b) investigated the tissue distribution of HOCs in freshwater fish community, and found that the significant accumulation of high lipophilic pollutants in liver tissue compared to other ones. Previous field study of frogs also detected the highest concentrations of HOCs in liver followed by muscle (Du et al., 2019), which might be explained by the fact that liver functioning as storage of glycogen and fat to apparent extent may cause the enhanced POP loads.

The snake liver and muscle samples shared close PBDE congener group patterns with enrichment of deca-BDE, which was very limited in snake lipid samples (Figure 1). The living habit may lead to the different congener group pattern in adipose tissues: reptiles would stop foraging and consume their body fat during brumation in winter; once adipose tissue was used, the highly lipophilic contaminants such as deca-BDE that were previously stored in lipid may redistribute among whole body. Although consumption of fat may reduce the $\mathrm{HOC}$ storage in snake adipose tissue, the redistribution process probably increased $\mathrm{HOC}$ in other tissues and eventually elevated the risk of exposure toxicity, which should be considered in biomonitoring (Du et al., 2020). Recent studies emphasized that the concentrations of PBDEs in different 
tissues may not entirely represent the tissue exposure, mainly due to the varying contaminant concentrations in wildlife tissues through time (Du et al., 2020). For example, HOC concentrations in adipose may be diluted by an increase of body fat (Yordy et al., 2010). In contrast, contaminant burdens are much steady and can reflect the whole exposure to tissues as well as individuals (Du et al., 2019).

In the present study, tissue-specific PBDE burdens of two snake species were calculated as the product of the tissue mass and tissue PBDE concentrations and presented in Figure 2. The body PBDE burdens (sum of three tissue burdens) in red-backed rat snake (400.2 ng) was two folds higher than those in short-tailed mamushi (188.6 ng). The red-backed rat snake individuals in the present study were generally thick in body condition since they had heavy body weight and high proportion in tissues (Table 1), in comparison with the short-tailed mamushi individuals which were considered to be thin. Yordy et al. (2010) also observed the higher contaminant burdens in fatter bottlenose dolphins. Animals with rich fat content may readily store lipophilic compounds in tissues. Simultaneously, there may be differences in metabolic activity between the two snake species, in particularly in snake liver and muscle, and these may be part of the explanation for the differences seen between the two species.

The relative contributions from liver, muscle and adipose tissues to the total PBDE burdens (sum of three tissue burdens) were similar between red-backed rat snake and short-ailed mamushi. The total burdens of two snakes were dominant by adipose (85.1\% and $80.0 \%$, respectively) while liver (8.1\% and $12.5 \%$, respectively) and muscle (6.9\% and 7.5\%, respectively) tissues had low proportion of the total burdens. For congener groups, high proportion of tri-BDE burdens were found in muscle tissue of red-backed rat snake (69.1\%) and short-tailed mamushi (76.4\%). Up to $80 \%$ of tetra- to nona-BDE burdens were enriched in adipose tissue of two snakes. For deca-BDE, liver tissue was the main storage tissue contributing to $43.6 \%$ of the burdens. These results indicated that the adipose tissue in snakes could serve as a more effective storage and sink for PBDE congeners compared to liver or muscle tissues. In HOC biomonitoring researches, measuring muscle or liver tissue concentrations was a common approach for assessing the chemical exposure in wildlife (Glüge et al., 2018; van Mourik et al., 2016). However, the overlook of adipose data may underestimate the exposure of PBDEs, in particular for animals with rich fat contents.

\subsection{Biomagnification Potential}

Biomagnification factors (BMFs) of HOC can be calculated by dividing the predator concentration by the prey concentration. Biomagnification is suggested to take place when the BMF value is higher than one. It is of great importance to confirm the predator and prey species in the food web (Glüge et al., 2018). Although snakes are generally seemed as a high trophic species, the diet of these feeders would vary with the environment. Most of red-backed rat snake preferred to live in/near water and choose the aquatic organisms that is the relative abundant and readily available. According to a snake dissection study in YRD, the pond loach, rice field eel and black-spotted frog were supposed as potential major diet for redbacked rat snakes in the local environment (Huang et al., 1990). Further assurance of predator-prey relationship was carried out using stable isotope analysis, and the analyzed $\delta_{13} \mathrm{C}$ and $\delta_{15} \mathrm{~N}$ values of redbacked rat snake and its prey candidates have been described in a previous study using the same 
samples (Du et al., 2020). $\delta_{13} \mathrm{C}$ values of red-backed rat snake and black-spotted frog were close (-23.76 $\pm 0.89 \%$ ond $-24.83 \pm 0.41 \%$ o, respectively) whereas red-backed rat snake was enriched in $\delta_{15} \mathrm{~N}(9.33 \pm$ $0.62 \%$ SD) compared with their diet $\left(7.36 \pm 1.21 \%\right.$ SD). For pond loach and rice field eel, the $\delta_{13} \mathrm{C}$ values were significantly lower than those observed in red-backed rat snakes $(p<0.05)$, which indicated that the pond loach and rice field eel were not the major carbon sources of red-backed rat snakes. These results confirmed the direct predator-prey relationship between the red-backed rat snakes and blackspotted frogs in the paddy field food web.

In the present study, biomagnification factors (BMFs) of PBDE congeners were calculated by dividing the lipid-normalized muscle concentration of red-backed rat snakes by the lipid-normalized muscle concentration of black-spotted frog. As shown in Figure 3, more than half of individual BDE congeners (13 out of 22) displayed BMF values above one. The BMF values of tri-BDE, tetra-BDE, penta-BDE, hexa$\mathrm{BDE}$, hepta-BDE, octa-BDE, nona-BDE and deca-BDE averaged at $0.75,2.30,1.62,2.61,3.10,4.30,0.85$ and 0.74 , respectively. In general, tetra- to octa-BDEs exhibited biomagnification potentials through the frog-snake food chain. The BMFs of PBDEs in the present study were comparable with those reported between predators and prey from an e-waste recycling site in South China (0.13-5,30) (Wu et al., 2020), but lower than those observed in the North Sea (0.6-15) (Weijs et al., 2009), the Atlantic coast (14-54) (Shaw et al., 2012), and the feeding experiment (7.2-20.6) (Luo et al., 2013). These results may suggested the trophic magnification potentials were affected by the behavior of predator and distinctive ecology, in which the food resource would vary markedly.

Parabolic relationship was observed between BMFs and log $K_{\text {ow }}$ values of PBDE congeners (Figure 3). The BMFs increased with increasing number of bromine atoms up to 8 and then rapidly declined as bromine atom number raised. It was noteworthy that the BMFs plots dropped dramatically after hepta$\mathrm{BDE}$ indicating the limited biomagnification potential of nona- and deca-BDEs $(\mathrm{Br} \geq 9)$ probably due to their very high molecular weight. Similar results have also been observed in bioaccumulation of PBDE (Wu et al., 2020), bioaccumulation of CPs (Sun et al., 2017a), trophic magnification of CPs (Zhou et al., 2018) and bioaccumulation study for other halogenated HOC (Zhu et al., 2015). PBDE congeners with higher bromine number tend to have higher log $K_{\text {ow }}$ values (Tittlemier et al., 2002; Yue and Li, 2013) resulting in higher biomagnification potential. However, the breakpoint from positive to negative correlation was approximately $\log K_{\mathrm{ow}}$ 8.6. The parabolic trend showed that the biomagnification potential of PBDE congeners appealed to be related to both hydrophobicity and molecular size of chemicals. The congener groups with low-moderate log $K_{\text {ow }}$ values (tri- to octa-BDEs) have smaller molecular size, and therefore, lipophilicity is the dominant factor. For congener groups with high log $K_{\text {ow }}$ values (nona- and deca-BDEs), larger molecular size may increase the difficulty of transmembrane and limit their bioavailability and biomagnification potential.

\section{Conclusions}


The present study presented one-hand data of tissue-specific levels and burdens of PBDE congeners in two snakes. The total PBDE concentrations of liver, muscle, and adipose tissues ranged from 29.1-252.2, 10.5-48.9 and 4.36-106.4 ng/g Iw, respectively. Tetra- to nona-BDEs were preferentially accumulated in snake adipose tissues while liver was an important storage and sink of deca-BDE. BMFs results through frog-snake food chain confirmed the varying biomagnification potentials for different PBDE congeners. Parabolic relationship was found between BMFs and log $K_{\mathrm{ow}}$ values of PBDE congeners, which may be resulted from the combined effects of hydrophobicity and molecular size of chemicals. Further research could focus on the toxicity, trophic transfer and biotransformation of PBDEs in different reptile tissues.

\section{Declarations}

Data availability: Most of the data generated or analysed during this study are included in this published article. In addition, the datasets used and/or analysed during the current study are not available.

Acknowledgments: We appreciate the samples provided by Shimadzu (China) Company and Tongji University.

Funding: This research received no external funding.

Contributions: Xiuming Jing: Conceptualization, Methodology, Writing original draft, Writing - Review and Editing, Software, Data Curation. Xueqiu Wang: Review and Editing, Formal analysis, and Supervision. Hongjuan Lv: Investigation, Data Curation. Futian Liu: Writing - Review and Editing, Software, Data Curation.

Corresponding author: Correspondence to Xueqiu Wang.

Ethics approval and consent to participate: Not applicable.

Consent for publication: Not applicable.

Conflicts of Interest: The authors declared that they have no conflicts of interest to this work.

\section{References}

1. Abbasi G, Buser AM, Soehl A, Murray MW, Diamond ML (2015) Stocks and Flows of PBDEs in Products from Use to Waste in the Us and Canada from 1970 to 2020. Environ Sci Technol 49:15211528

2. Besis A, Samara C (2012) Polybrominated Diphenyl Ethers (PBDEs) in the Indoor and Outdoor Environments - a Review on Occurrence and Human Exposure. Environ Pollut 169:217-229

3. Chabot-Giguere B, Letcher RJ, Verreault J (2013) In Vitro Biotransformation of Decabromodiphenyl Ether (Bde-209) and Dechlorane Plus Flame Retardants: A Case Study of Ring-Billed Gull Breeding in a Pollution Hotspot in the St. Lawrence River, Canada. Environ Int 55:101-108 
4. Conder JM, Hoke RA, De Wolf W, Russell MH, Buck RC (2008) Are Pfcas Bioaccumulative? A Critical Review and Comparison with Regulatory Criteria and Persistent Lipophilic Compounds. Environ Sci Technol 42:995-1003

5. Currier HA, Fremlin KM, Elliott JE, Drouillard KG, Williams TD (2020) Bioaccumulation and Biomagnification of PBDEs in a Terrestrial Food Chain at an Urban Landfill. Chemosphere 238

6. Domingo JL (2012) Polybrominated Diphenyl Ethers in Food and Human Dietary Exposure: A Review of the Recent Scientific Literature. Food Chem Toxicol 50:238-249

7. Du X, Yuan B, Zhou Y, Benskin JP, Qiu Y, Yin G, Zhao J (2018) Short-, Medium-, and Long-Chain Chlorinated Paraffins in Wildlife from Paddy Fields in the Yangtze River Delta. Environ Sci Technol 52:1072-1080

8. Du XY, Yuan B, Zhou YH, de Wit CA, Zheng ZY, Yin G (2020) Chlorinated Paraffins in Two Snake Species from the Yangtze River Delta: Tissue Distribution and Biomagnification. Environ Sci Technol 54:2753-2762

9. Du XY, Yuan B, Zhou YH, Zheng ZY, Wu Y, Qiu YL, Zhao JF, Yin G (2019) Tissue-Specific Accumulation, Sexual Difference, and Maternal Transfer of Chlorinated Paraffins in Black-Spotted Frogs. Environ Sci Technol 53:4739-4746

10. Glüge J, Schinkel L, Hungerbühler K, Cariou R, Bogdal C (2018) Environmental Risks of MediumChain Chlorinated Paraffins (MCCPs)-a Review. Environmental science \& technology

11. Hites RA (2004) Polybrominated Diphenyl Ethers in the Environment and in People: A Meta-Analysis of Concentrations. Environ Sci Technol 38:945-956

12. Hopkins WA (2000) Reptile Toxicology: Challenges and Opportunities on the Last Frontier in Vertebrate Ecotoxicology. Environ Toxicol Chem 19:2391-2393

13. Huang M, Jin Y, Cai C (1990) Zhejiang Fauna Sinica: Reptilia. Zhejiang Science and Technology Press

14. Johnson-Restrepo B, Kannan K, Addink R, Adams DH (2005) Polybrominated Diphenyl Ethers and Polychlorinated Biphenyls in a Marine Foodweb of Coastal Florida. Environ Sci Technol 39:82438250

15. Kelly BC, Ikonomou MG, Blair JD, Gobas FA (2008) Bioaccumulation Behaviour of Polybrominated Diphenyl Ethers (PBDEs) in a Canadian Arctic Marine Food Web. Sci Total Environ 401:60-72

16. Li J, Wang J, Taylor AR, Cryder Z, Schlenk D, Gan J (2019) Inference of Organophosphate Ester Emission History from Marine Sediment Cores Impacted by Wastewater Effluents. Environ Sci Technol 53:8767-8775

17. Li J, Yuan GL, Li P, Duan XC, Yu HH, Qiu JL, Wang GH (2018) Insight into the Local Source of Polybrominated Diphenyl Ethers in the Developing Tibetan Plateau: The Composition and Transport around the Lhasa Landfill. Environ Pollut 237:1-9

18. Liu Y, Luo XJ, Huang LQ, Tao L, Zeng YH, Mai BX (2018) Halogenated Organic Pollutants in Aquatic, Amphibious, and Terrestrial Organisms from an E-Waste Site: Habitat-Dependent Accumulation and Maternal Transfer in Watersnake. Environ Pollut 241:1063-1070 
19. Luo XJ, Zeng YH, Chen HS, Wu JP, Chen SJ, Mai BX (2013) Application of Compound-Specific Stable Carbon Isotope Analysis for the Biotransformation and Trophic Dynamics of PBDEs in a Feeding Study with Fish. Environ Pollut 176:36-41

20. Schecter A, Papke O, Tung KC, Staskal D, Birnbaum L (2004) Polybrominated Diphenyl Ethers Contamination of United States Food. Environ Sci Technol 38:5306-5311

21. Sharkey M, Harrad S, Abou-Elwafa Abdallah M, Drage DS, Berresheim H (2020) Phasing-out of Legacy Brominated Flame Retardants: The Unep Stockholm Convention and Other Legislative Action Worldwide. Environ Int 144:106041

22. Shaw SD, Berger ML, Weijs L, Covaci A (2012) Tissue-Specific Accumulation of Polybrominated Diphenyl Ethers (PBDEs) Including Deca-Bde and Hexabromocyclododecanes (Hbcds) in Harbor Seals from the Northwest Atlantic. Environ Int 44:1-6

23. Sjodin A, Patterson DG, Bergman A (2003) A Review on Human Exposure to Brominated Flame Retardants - Particularly Polybrominated Diphenyl Ethers. Environ Int 29:829-839

24. Sparling DW, Linder G, Bishop CA, Krest S (2010)Ecotoxicology of Amphibians and Reptiles. CRC Press

25. Stapleton HM, Klosterhaus S, Keller A, Ferguson PL, van Bergen S, Cooper E, Webster TF, Blum A (2011) Identification of Flame Retardants in Polyurethane Foam Collected from Baby Products. Environ Sci Technol 45:5323-5331

26. Sun R, Luo X, Tang B, Chen L, Liu Y, Mai B (2017a) Bioaccumulation of Short Chain Chlorinated Paraffins in a Typical Freshwater Food Web Contaminated by E-Waste in South China: Bioaccumulation Factors, Tissue Distribution, and Trophic Transfer. Environ Pollut 222:165-174

27. Sun RX, Luo XJ, Tang B, Chen LG, Liu Y, Mai BX (2017b) Bioaccumulation of Short Chain Chlorinated Paraffins in a Typical Freshwater Food Web Contaminated by E-Waste in South China:

Bioaccumulation Factors, Tissue Distribution, and Trophic Transfer. Environ Pollut 222:165-174

28. Tittlemier SA, Halldorson T, Stern GA, Tomy GT (2002) Vapor Pressures, Aqueous Solubilities, and Henry's Law Constants of Some Brominated Flame Retardants. Environ Toxicol Chem 21:1804-1810

29. van Mourik LM, Gaus C, Leonards PE, de Boer J (2016) Chlorinated Paraffins in the Environment: A Review on Their Production, Fate, Levels and Trends between 2010 and 2015. Chemosphere 155:415-428

30. Weijs L, Dirtu AC, Das K, Gheorghe A, Reijnders PJH, Neels H, Blust R, Covaci A (2009) Inter-Species Differences for Polychlorinated Biphenyls and Polybrominated Diphenyl Ethers in Marine Top Predators from the Southern North Sea: Part 2. Biomagnification in Harbour Seals and Harbour Porpoises. Environ Pollut 157:445-451

31. Wu JP, She YZ, Zhang Y, Peng Y, Mo L, Luo XJ, Mai BX (2013) Sex-Dependent Accumulation and Maternal Transfer of Dechlorane Plus Flame Retardant in Fish from an Electronic Waste Recycling Site in South China. Environ Pollut 177:150-155

32. Wu JP, Wu SK, Tao L, She YZ, Chen XY, Feng WL, Zeng YH, Luo XJ, Mai BX (2020) Bioaccumulation Characteristics of PBDEs and Alternative Brominated Flame Retardants in a Wild Frog-Eating 
Snake.Environ. Pollut.258

33. Wu T, Hong B, Wu XB, Wu JP, Wang XM, Yi ZG, Zhao J, Zhan M, Mai BX (2014) Persistent Halogenated Compounds in Captive Chinese Alligators (Alligator Sinensis) from China. Chemosphere 110:23-30

34. Yordy JE, Pabst DA, McLellan WA, Wells RS, Rowles TK, Kucklick JR (2010) Tissue-Specific Distribution and Whole-Body Burden Estimates of Persistent Organic Pollutants in the Bottlenose Dolphin (Tursiops Truncatus). Environ Toxicol Chem 29:1263-1273

35. Yue CY, Li LY (2013) Filling the Gap: Estimating Physicochemical Properties of the Full Array of Polybrominated Diphenyl Ethers (PBDEs). Environ Pollut 180:312-323

36. Zhou Y, Chen Q, Du X, Yin G, Qiu Y, Ye L, Zhu Z, Zhao J (2016a) Occurrence and Trophic Magnification of Polybrominated Diphenyl Ethers (PBDEs) and Their Methoxylated Derivatives in Freshwater Fish from Dianshan Lake, Shanghai, China. Environ Pollut 219:932-938

37. Zhou Y, Yin G, Du X, Xu M, Qiu Y, Ahlqvist P, Chen Q, Zhao J (2018) Short-Chain Chlorinated Paraffins (SCCPs) in a Freshwater Food Web from Dianshan Lake: Occurrence Level, Congener Pattern and Trophic Transfer. Sci Total Environ 615:1010-1018

38. Zhou YH, Asplund L, Yin G, Athanassiadis I, Wideqvist U, Bignert A, Qiu YL, Zhu ZL, Zhao JF, Bergman A (2016b) Extensive Organohalogen Contamination in Wildlife from a Site in the Yangtze River Delta. Sci Total Environ 554:320-328

39. Zhu C, Wang P, Li Y, Chen Z, Li W, Ssebugere P, Zhang Q, Jiang G (2015) Bioconcentration and Trophic Transfer of Polychlorinated Biphenyls and Polychlorinated Dibenzo-P-Dioxins and Dibenzofurans in Aquatic Animals from an E-Waste Dismantling Area in East China. Environ Sci Process Impacts 17:693-699

\section{Figures}




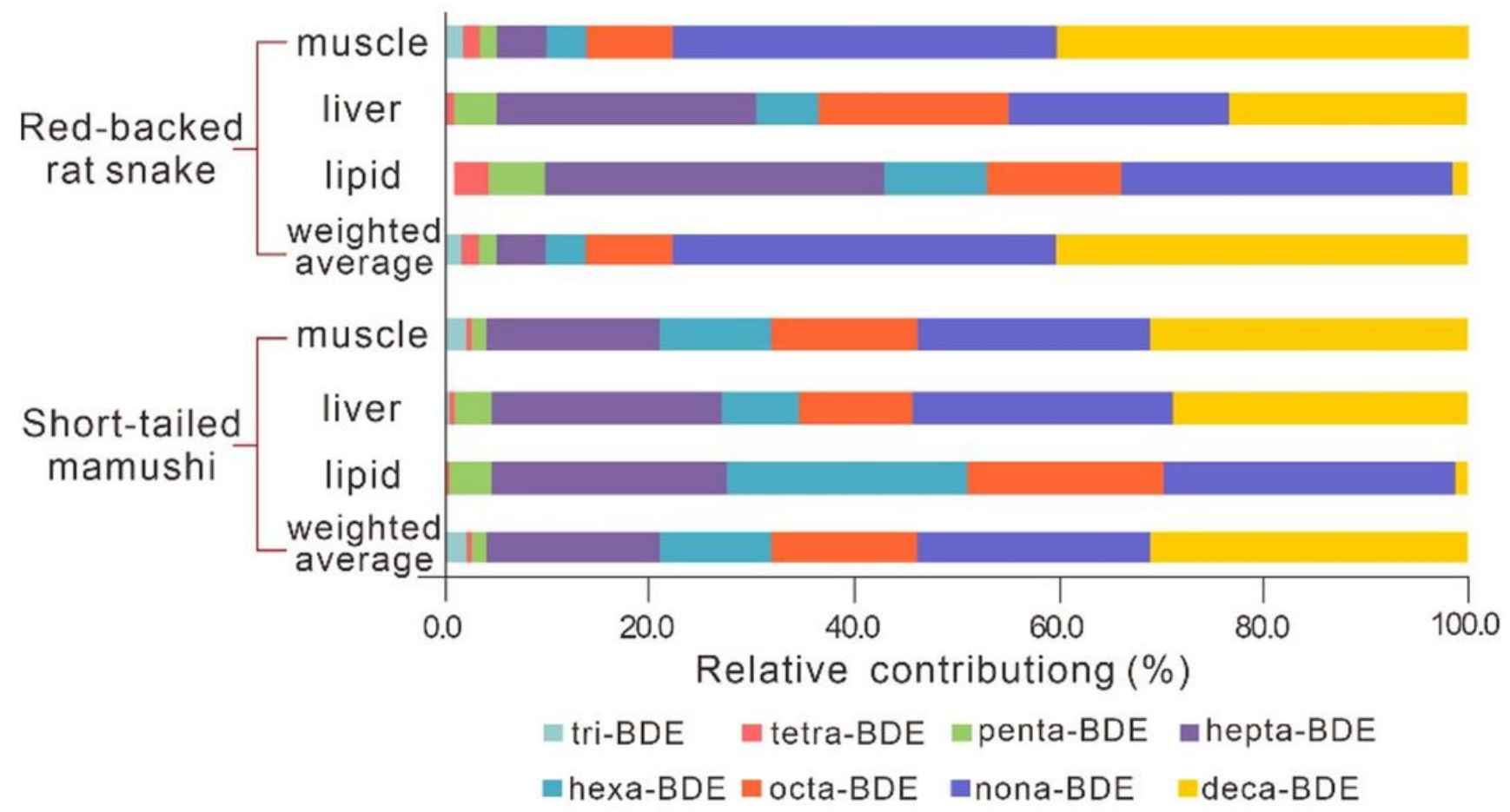

Figure 1

Congener group pattern of PBDEs in muscle, liver, and adipose of two snake species 


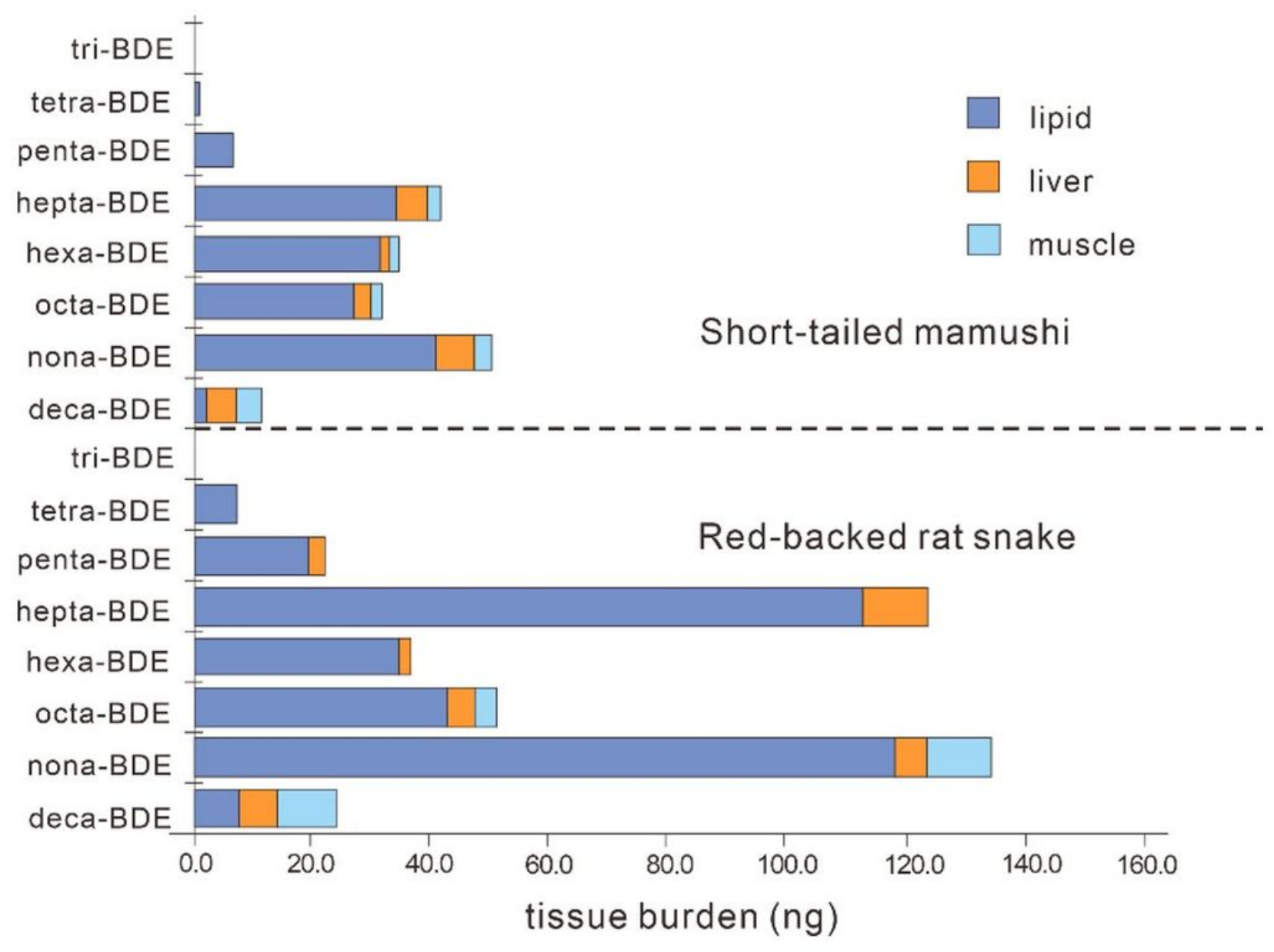

Figure 2

Tissue-specific burdens of tri- to deca-BDEs (ng) in two snake species 


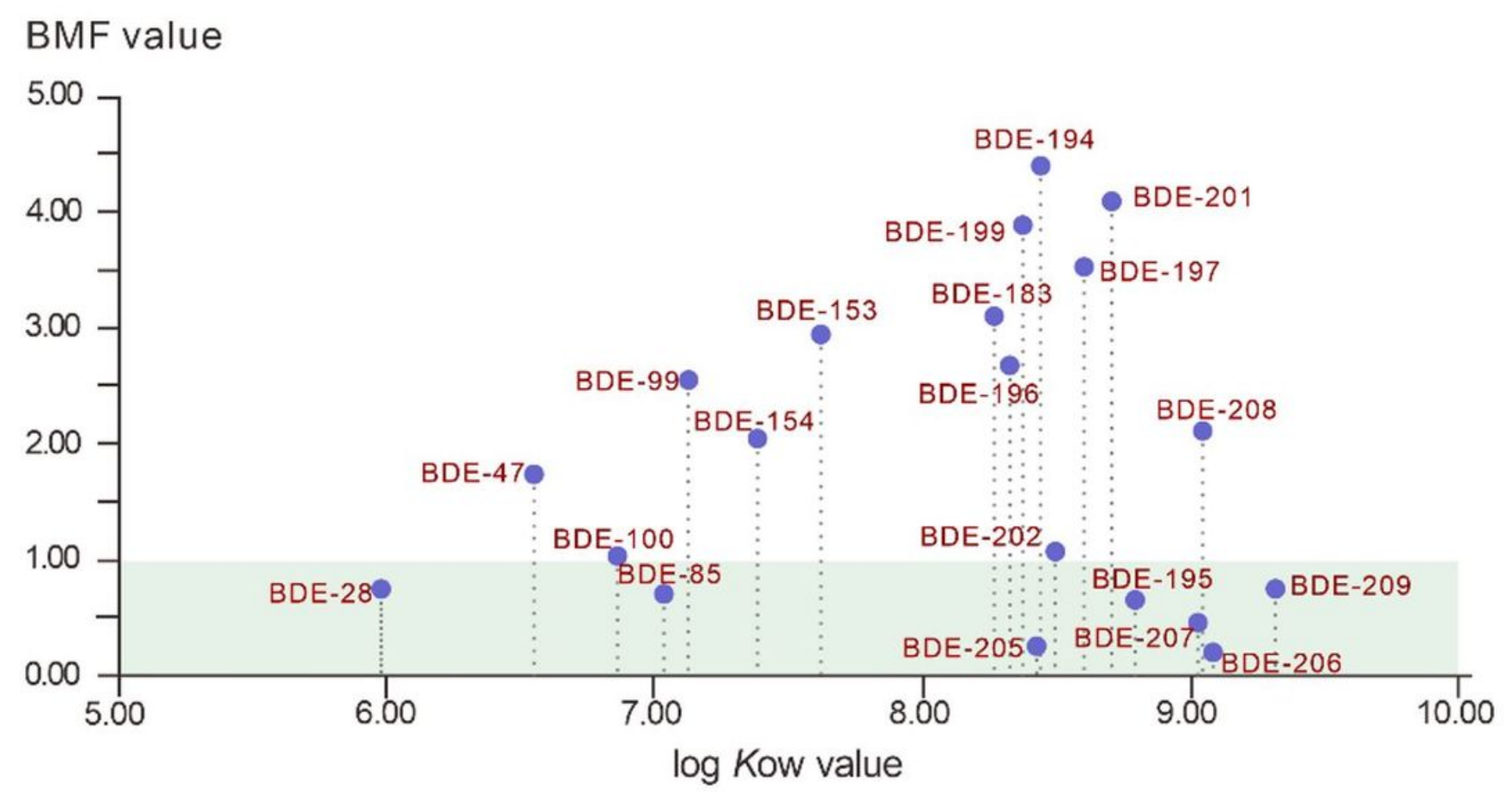

Figure 3

Biomagnification factors (BMFs) of PBDE congeners derived from the the red-backed rat snake/ blackspotted frog relationship. The green rectangle represents BMF values less than 1, BMFs above which may suggest biomagnification 